UDC 519.6

$10.23947 / 2587-8999-2019-1-1-1-16$

\title{
Improvement of numerical solution smoothness for the hydrodynamics problems modeling on rectangular grids *
}

\section{A.I. Sukhinov, A.E. Chistyakov**, E.A. Protsenko, V.V. Sidoryakina***, S.V. Protsenko **}

Don State Technical University, Rostov-on-Don, Russia

Chekhov Taganrog Institute Taganrog branch of Rostov State University of Economics, Taganrog, Russia

The article has been devoted to the problem of improvement real numerical modeling accuracy for the viscous fluid flow between two coaxial half-cylinders on rectangular grids taking into account the filling of cells are used to solve this problem. Approximation of the problem with respect to time is performed on the basis of splitting schemes for physical processes. Difference schemes for solving the hydrodynamic problem are proposed. Analytic solution describing the Taylor-Couette flow is used as a standard to evaluate the numerical solution accuracy of hydrodynamics problems. The simulation was performed on a sequence of condensing computed grids of sizes $11 \times 21,21 \times 41,41$ $\times 81$, and $81 \times 161$ nodes for the areas of smooth and piecewise rectangular boundaries. The grids taking into account the filling of cells are used to improve the smoothness of the solution. In the case of piecewise rectangular approximation the numerical solution error reaches $70 \%$. The grids taking into account the filling of cells reduce the numerical solution error to $6 \%$ for the test problem. The test problem shows that using the grid condenced in each spatial direction by 8 times does not lead to increasing the accuracy solutions whereas the solutions accuracy obtained on the basis proposed approach has significant advantage in accuracy.

Keywords: Navier-Stokes equation, splitting schemes for physical processes, the TaylorCouette flow, the error of numerical solution.

Introduction. Difference schemes taking into account the degree the filling of cells for solving two-dimensional problems of wave hydrodynamics with dynamically varied geometry of the computational domain were proposed in [1]. The solutions obtained on the basis of these schemes are devoid of defects associated with graded approximation of the boundary. Tree-dimensional mathematical model of the movement of the water medium in the Azov Sea was developed on the basis of these schemes [2], the total water depth was 14.2 meters, free surface elevation may be reach 4 meters or more. The dynamic recalculation of the filling of cells is used as a mechanism for reconstructing the geometry of the reservoir. The model possesses high accuracy and a large margin

\footnotetext{
* The work was supported by the RSF (project No. 17-11-01286).

**E-mail: sukhinov@gmail.com,cheese_05@mail.ru,rab55555@rambler.ru.

*** E-mail: eapros@rambler.ru,cvv9@mail.ru.
} 
of stability. During calculating the storm surge that occurred in September 2014, in Taganrog bay of Azov sea (wind speed reached $40 \mathrm{~m} / \mathrm{s}$ ), the simulation error was $20 \mathrm{~cm}$ with a total over travel of more than 4 meters, the model showed a time lag of about 15 minutes with a total storm interval of about 1000 minutes [3]. The $\sigma$-coordinate system is traditionally used in modeling the hydrodynamics of shallow water bodies [4-6]. The solutions obtained on these grids have a large error and poorly describe the influence of the bottom relief on nowadays the structure of the currents. The optimal curvilinear grids that approximate the boundary ear used as an alternative to rectangular grids, which have low accuracy in the case of direct piecewise rectangular approximation of the boundary [7-8].

The constructing problem of optimal three-dimensional computational grids remains open nowadays for the 3D regions of common configurations in computational fluid dynamics [9]. One can say without reducing the significant value of optimal curvilinear grids for computational fluid dynamics, that using rectangular grids with filling cell functions has attractive features, for example in parallel computational fluid dynamics. Difference schemes accuracy comparison has been discussed in this paper in cases of direct rectangular grids usage and additional involvement of the cell filling function for the Taylor-Couette flow numerical modeling. The proposed method is likely close to Volume Of Fluid (VOF) method [10, 11].

Statement of the problem. The viscous incompressible fluid motion in a two-dimensional region between two infinitely long coaxial circular cylinders is considered. We introduce the Cartesian coordinate system $x O y$ perpendicular to the axis of the cylinders. The coordinate system origin coincides with the cylinders' axis. In the section of the cylinder by the plane $x=0$ defines the field of velocity. It is required to determine the liquid motion. The initial equations for the mathematical description of the fluid dynamics problem are [12, 13]:

- Navier-Stokes equation:

$$
\begin{aligned}
& u_{t}^{\prime}+u u_{x}^{\prime}+v u_{y}^{\prime}=-\frac{P_{x}^{\prime}}{\rho}+\left(\mu u_{x}^{\prime}\right)_{x}^{\prime}+\left(\mu u_{y}^{\prime}\right)_{y}^{\prime}, \\
& v_{t}^{\prime}+u v_{x}^{\prime}+v v_{y}^{\prime}=-\frac{P_{y}^{\prime}}{\rho}+\left(\mu v_{x}^{\prime}\right)_{x}^{\prime}+\left(\mu v_{y}^{\prime}\right)_{y}^{\prime} ;
\end{aligned}
$$

- the continuity equation for incompressible fluid:

$u_{x}^{\prime}+v_{y}^{\prime}=0$.

Equations (1)-(3) are considered under the following boundary conditions:

- the flows are defined on the input and output boundaries:

$u(x, y, t)=U(x, y), v(x, y, t)=V(x, y), P_{n}^{\prime}(x, y, t)=0$,

- the frictionless and slip conditions are set on the lateral surfaces (in the case $|\boldsymbol{\tau}|=0$, that is, without friction):

$$
P_{n}^{\prime}(x, y, t)=0, \mathbf{u}_{n}(x, y, t)=0, \rho \mu u_{y}^{\prime}(x, y, t)=-\tau_{x}(t), \rho \mu v_{x}^{\prime}(x, y, t)=-\tau_{y}(t)
$$

or sticking condition:

$$
P_{n}^{\prime}(x, y, t)=0, u(x, y, t)=0, v(x, y, t)=0,
$$

where $\mathbf{u}=\{u, v\}$ is the water medium velocity vector; $(x, y)$ is Cartesian coordinates, $t$ is time, $P$ is pressure; $\mu$ is the turbulent exchange coefficient; $\rho$ is the liquid density; $n$ is the normal vector; 
$\tau_{x}, \tau_{y}$ are the tangential stress components at the bottom of the liquid.

The wind stress according to the Van Dorn law, is calculated by the formulas [6]:

$$
\boldsymbol{\tau} \equiv\left\{\tau_{x}, \tau_{y}\right\}=\rho_{v} C_{p}(|\mathbf{u}|) \mathbf{u}|\mathbf{u}|, C_{p}(|\mathbf{u}|)=\left\{\begin{array}{l}
0.0088,|\mathbf{u}|<6,6 \mathrm{~m} / c, \\
0.0026,|\mathbf{u}| \geq 6,6 \mathrm{~m} / c,
\end{array}\right.
$$

where $\rho_{v}$ is the external environment density.

Discrete model of hydrodynamics. The computational domain inscribed in a rectangle. For numerical realization of the discrete mathematical model of the formulated wave hydrodynamics problem, uniform grid is introduced:

$$
\begin{gathered}
w_{h}=\left\{t^{n}=n \tau, x_{i}=i h_{x}, y_{j}=j h_{y} ; n=\overline{0, \ldots, N_{t}}, i=\overline{0, \ldots, N_{x}}, j=\overline{0, \ldots, N_{y}} ;\right. \\
\left.N_{t} \tau=T, N_{x} h_{x}=l_{x}, N_{y} h_{y}=l_{y}\right\},
\end{gathered}
$$

where $\tau$ is the time step, $h_{x}, h_{y}$ are steps in space, $N_{t}$ is the step number on the time coordinate, $N_{x}, N_{y}$ are spacing steps on the spatial coordinates $x$ and $y$, respectively.

We use the splitting schemes for physical processes $[14,15]$. In this case, the solution of the problem (1)-(3) reduces to solving the following system of equations:

$$
\begin{aligned}
& \frac{u^{n+\sigma}-u^{n}}{\tau}+u u_{x}^{\prime}+v u_{y}^{\prime}=\left(\mu u_{x}^{\prime}\right)_{x}^{\prime}+\left(\mu u_{y}^{\prime}\right)_{y}^{\prime}, \\
& \frac{v^{n+\sigma}-v^{n}}{\tau}+u v_{x}^{\prime}+v v_{y}^{\prime}=\left(\mu v_{x}^{\prime}\right)_{x}^{\prime}+\left(\mu v_{y}^{\prime}\right)_{y}^{\prime}, \\
& P_{x x}^{\prime \prime}+P_{y y}^{\prime \prime}=\frac{\rho}{\tau}\left(\left(u^{n+\sigma}\right)_{x}^{\prime}+\left(v^{n+\sigma}\right)_{y}^{\prime}\right), \\
& \frac{u^{n+1}-u^{n+\sigma}}{\tau}=-\frac{P_{x}^{\prime}}{\rho}, \frac{v^{n+1}-v^{n+\sigma}}{\tau}=-\frac{P_{y}^{\prime}}{\rho} .
\end{aligned}
$$

The calculated cells are rectangles, which may be filled, partially filled, or empty. The cell centers and nodes are separated apart $h_{x} / 2$ and $h_{y} / 2$ on the coordinates $x$ and $y$, respectively. Fig. 1 shows that the velocity field and pressure are calculated at the tops of the cells. The cells' vertices $(i, j)$ are nodes $(i, j),(i-1, j),(i, j-1),(i-1, j-1)$.

Let us introduce grid value $o_{i, j}$ for the notation of the cell filling. The filling of cells means the value of cell part volume (area) which has been filled with a liquid medium. Fig. 2 shows that in the neighborhood of the node are cells $(i, j),(i+1, j),(i, j+1),(i+1, j+1)$.

We introduce the coefficients $k_{0}, k_{1}, k_{2}, k_{3}, k_{4}$, describing the filling of regions located in the neighborhood of the cell. The value $k_{0}$ characterizes the filling of the region $\Omega_{0}: x \in\left(x_{i-1}, x_{i+1}\right)$, $y \in\left(y_{j-1}, y_{j+1}\right), k_{1}-\Omega_{1}: x \in\left(x_{i}, x_{i+1}\right), y \in\left(y_{j-1}, y_{j+1}\right), k_{2}-\Omega_{2}: x \in\left(x_{i-1}, x_{i}\right), y \in\left(y_{j-1}, y_{j+1}\right), k_{3}-$ $\Omega_{3}: x \in\left(x_{i-1}, x_{i+1}\right), y \in\left(y_{j}, y_{j+1}\right), k_{4}-\Omega_{4}: x \in\left(x_{i-1}, x_{i+1}\right), y \in\left(y_{j-1}, y_{j}\right)$. The filled parts of the regions $\Omega_{m}$ is called $D_{m}$, where $m=\overline{0, \ldots, 4}$. The coefficients $k_{m}$ can be calculated from the 
formulas:

$$
\begin{gathered}
\left(k_{m}\right)_{i, j}=\frac{S_{D_{m}}}{S_{\Omega_{m}}},\left(k_{0}\right)_{i, j}=\frac{o_{i, j}+o_{i+1, j}+o_{i+1, j+1}+o_{i, j+1}}{4},\left(k_{1}\right)_{i, j}=\frac{o_{i+1, j}+o_{i+1, j+1}}{2} \\
\left(k_{2}\right)_{i, j}=\frac{o_{i, j}+o_{i, j+1}}{2},\left(k_{3}\right)_{i, j}=\frac{o_{i+1, j+1}+o_{i, j+1}}{2},\left(k_{4}\right)_{i, j}=\frac{o_{i, j}+o_{i+1, j}}{2}
\end{gathered}
$$

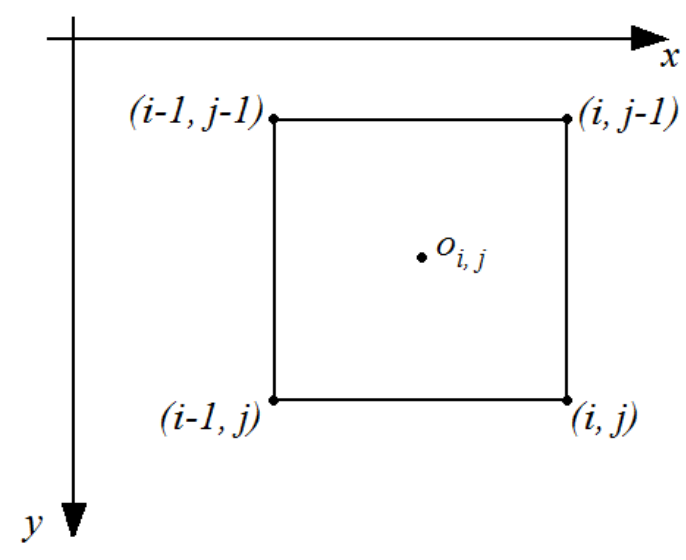

Fig. 1. The cell location of the relative to the adjacent nodes

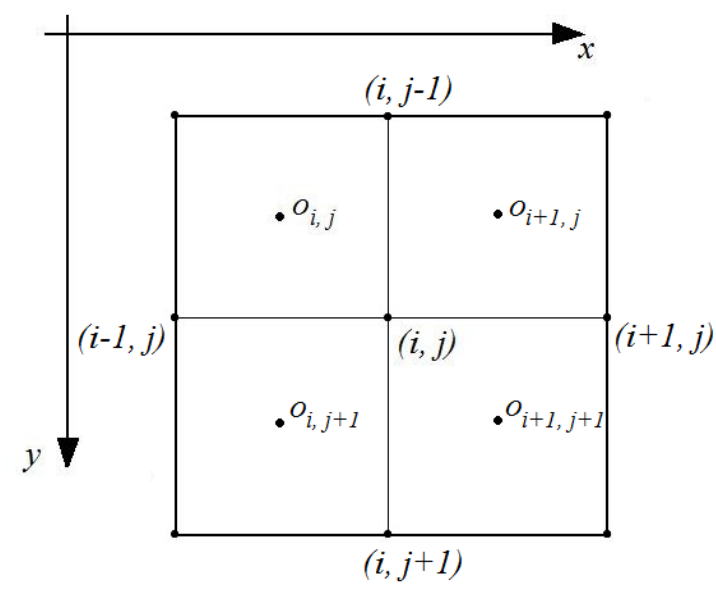

Fig. 2. The arrangement of nodes relative to cells

The boundary conditions for the first subproblem of wave hydrodynamics (8), (9) take form:

$$
\begin{aligned}
& u_{x}^{\prime}(x, y, t)=\alpha_{u, x} u+\beta_{u, x}, \quad v_{x}^{\prime}(x, y, t)=\alpha_{v, x} v+\beta_{v, x}, \\
& u_{y}^{\prime}(x, y, t)=\alpha_{u, y} u+\beta_{u, y}, \quad v_{y}^{\prime}(x, y, t)=\alpha_{v, y} v+\beta_{v, y} .
\end{aligned}
$$

We integrate equation (8) over the region $D_{0}$ and use the property of linearity of the integral, as a result of which we obtain:

$$
\iint_{D_{0}} \frac{u^{n+\sigma}-u^{n}}{\tau} d x d y+\iint_{D_{0}} u u_{x}^{\prime} d x d y+\iint_{D_{0}} v u_{y}^{\prime} d x d y=\iint_{D_{0}}\left(\mu u_{x}^{\prime}\right)_{x}^{\prime} d x d y+\iint_{D_{0}}\left(\eta u_{y}^{\prime}\right)_{y}^{\prime} d x d y .
$$

After calculating separately each of the integrals we obtain:

$$
\iint_{D_{0}} \frac{u^{n+\sigma}-u^{n}}{\tau} d x d y \square\left(k_{0}\right)_{i, j} \iint_{\Omega_{0}} \frac{u^{n+\sigma}-u^{n}}{\tau} d x d y=\left(k_{0}\right)_{i, j} \frac{u_{i, j}^{n+\sigma}-u_{i, j}^{n}}{\tau} h_{x} h_{y} .
$$

The second integral in expression (13) may be written in the form:

$$
\iint_{D_{0}} u u_{x}^{\prime} d x d y=\iint_{D_{1}} u u_{x}^{\prime} d x d y+\iint_{D_{2}} u u_{x}^{\prime} d x d y \square\left(k_{1}\right)_{i, j} \iint_{\Omega_{1}} u u_{x}^{\prime} d x d y+\left(k_{2}\right)_{i, j} \iint_{\Omega_{2}} u u_{x}^{\prime} d x d y \text {. }
$$

Calculating the integrals over the regions $\Omega_{1}$ and $\Omega_{2}$, we obtain

$$
\iint_{D_{0}} u u_{x}^{\prime} d x d y=\frac{\left(k_{1}\right)_{i, j} u_{i+1 / 2, j} h_{y}\left(u_{i+1, j}-u_{i, j}\right)+\left(k_{2}\right)_{i, j} u_{i-1 / 2, j} h_{y}\left(u_{i, j}-u_{i-1, j}\right)}{2} .
$$

We calculate the integral on the right-hand side of expression (13): 


$$
\iint_{D_{0}}\left(\mu u_{x}^{\prime}\right)_{x}^{\prime} d x d y=\iint_{D_{1}}\left(\mu u_{x}^{\prime}\right)_{x}^{\prime} d x d y+\iint_{D_{2}}\left(\mu u_{x}^{\prime}\right)_{x}^{\prime} d x d y
$$

In the last equality, let us assume that $S_{D_{1}}>S_{D_{2}}$, where we select from the region $D_{1}$ fragment $D_{1,2}$, adjacent to the region $D_{2}$, and $S_{D_{2}}=S_{D_{1,2}}$ (Fig. 3).

$$
\begin{aligned}
& \iint_{D_{0}}\left(\mu u_{x}^{\prime}\right)_{x}^{\prime} d x d y=\iint_{D_{1} D_{1,2}}\left(\mu u_{x}^{\prime}\right)_{x}^{\prime} d x d y+\iint_{D_{1,2} \cup D_{2}}\left(\mu u_{x}^{\prime}\right)_{x}^{\prime} d x d y \\
& \square\left(\left(k_{1}\right)_{i, j}-\left(k_{2}\right)_{i, j}\right) \iint_{\Omega_{1}}\left(\mu u_{x}^{\prime}\right)_{x}^{\prime} d x d y+\left(k_{2}\right)_{i, j} \iint_{\Omega_{0}}\left(\mu u_{x}^{\prime}\right)_{x}^{\prime} d x d y .
\end{aligned}
$$

As a result, we get:

$$
\begin{aligned}
& \iint_{D_{0}}\left(\mu u_{x}^{\prime}\right)_{x}^{\prime} d x d y \square\left(\left(k_{1}\right)_{i, j} \mu_{i+1 / 2, j} \frac{u_{i+1, j}-u_{i, j}}{h_{x}}-\left(k_{2}\right)_{i, j} \mu_{i-1 / 2, j} \frac{u_{i, j}-u_{i-1, j}}{h_{x}}-\right. \\
& \left.-\left(\left(k_{1}\right)_{i, j}-\left(k_{2}\right)_{i, j}\right) \mu_{i, j}\left(\alpha_{u, x} u_{i, j}+\beta_{u, x}\right)\right) h_{y} .
\end{aligned}
$$

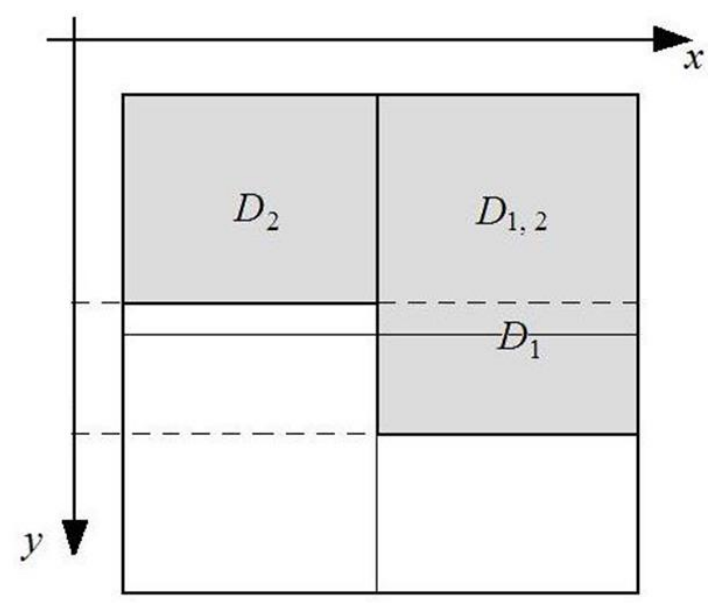

Fig. 3. The scheme of the domain filling

In case, if $S_{D_{2}}>S_{D_{1}}$, the result will be similar. Substituting into equation (13), the expressions (14) - (16), we readily obtain:

$$
\begin{aligned}
& \left(k_{0}\right)_{i, j} \frac{u_{i, j}^{n+\sigma}-u_{i, j}^{n}}{\tau} h_{x} h_{y}+\left(\left(k_{1}\right)_{i, j} u_{i+1 / 2, j} h_{y}\left(u_{i+1, j}-u_{i, j}\right)+\left(k_{2}\right)_{i, j} u_{i-1 / 2, j} h_{y}\left(u_{i, j}-u_{i-1, j}\right)\right) / 2+ \\
& +\left(\left(k_{3}\right)_{i, j} v_{i, j+1 / 2} h_{x}\left(u_{i, j+1}-u_{i, j}\right)+\left(k_{4}\right)_{i, j} v_{i, j-1 / 2} h_{x}\left(u_{i, j}-u_{i, j-1}\right)\right) / 2= \\
& =\left(\left(k_{1}\right)_{i, j} \mu_{i+1 / 2, j} \frac{u_{i+1, j}-u_{i, j}}{h_{x}}-\left(k_{2}\right)_{i, j} \mu_{i-1 / 2, j} \frac{u_{i, j}-u_{i-1, j}}{h_{x}}-\right. \\
& \left.-\left(\left(k_{1}\right)_{i, j}-\left(k_{2}\right)_{i, j}\right) \mu_{i, j}\left(\alpha_{u, x} u_{i, j}+\beta_{u, x}\right)\right) h_{y}+\left(\left(k_{3}\right)_{i, j} \eta_{i, j+1 / 2} \frac{u_{i, j+1}-u_{i, j}}{h_{y}}-\right.
\end{aligned}
$$




$$
\left.-\left(k_{4}\right)_{i, j} \eta_{i, j-1 / 2} \frac{u_{i, j}-u_{i, j-1}}{h_{y}}-\left(\left(k_{3}\right)_{i, j}-\left(k_{4}\right)_{i, j}\right) \eta_{i, j}\left(\alpha_{u, y} u_{i, j}+\beta_{u, y}\right)\right) h_{x} \text {. }
$$

If we divide the obtained expression by the area of the cell $h_{x} h_{y}$ we are coming to:

$$
\begin{aligned}
& \left(k_{0}\right)_{i, j} \frac{u_{i, j}^{n+\sigma}-u_{i, j}^{n}}{\tau}+\left(k_{1}\right)_{i, j} u_{i+1 / 2, j} \frac{u_{i+1, j}-u_{i, j}}{2 h_{x}}+\left(k_{2}\right)_{i, j} u_{i-1 / 2, j} \frac{u_{i, j}-u_{i-1, j}}{2 h_{x}}+ \\
& +\left(k_{3}\right)_{i, j} v_{i, j+1 / 2} \frac{u_{i, j+1}-u_{i, j}}{2 h_{y}}+\left(k_{4}\right)_{i, j} v_{i, j-1 / 2} \frac{u_{i, j}-u_{i, j-1}}{2 h_{y}}=\left(k_{1}\right)_{i, j} \mu_{i+1 / 2, j} \frac{u_{i+1, j}-u_{i, j}}{h_{x}^{2}}- \\
& -\left(k_{2}\right)_{i, j} \mu_{i-1 / 2, j} \frac{u_{i, j}-u_{i-1, j}}{h_{x}^{2}}-\left(\left(k_{1}\right)_{i, j}-\left(k_{2}\right)_{i, j}\right) \mu_{i, j} \frac{\alpha_{u, x} u_{i, j}+\beta_{u, x}}{h_{x}}+ \\
& +\left(k_{3}\right)_{i, j} \eta_{i, j+1 / 2} \frac{u_{i, j+1}-u_{i, j}}{h_{y}^{2}}-\left(k_{4}\right)_{i, j} \eta_{i, j-1 / 2} \frac{u_{i, j}-u_{i, j-1}}{h_{y}^{2}}-\left(\left(k_{3}\right)_{i, j}-\left(k_{4}\right)_{i, j}\right) \eta_{i, j} \frac{\alpha_{u, y} u_{i, j}+\beta_{u, y}}{h_{y}} .
\end{aligned}
$$

In a similar way, one can obtain discrete analogs for equations (9)-(12). In order to simplify the recording of equations, a «mask» of the boundary condition $m_{i, j}$ is introduced. The parameter $m_{i, j}$ takes the value 1 if the node $(i, j)$ belongs to the boundary nodes set located in the border region where slip occurs with friction, otherwise $m_{i, j}=0$. The discrete model of the hydrodynamic problem may be represented by the following grid equations [16]:

- for the component of the velocity vector $u_{i, j}$ under slip condition:

$$
\begin{aligned}
& \left(k_{0}\right)_{i, j} \frac{u_{i, j}^{n+\sigma}-u_{i, j}^{n}}{\tau}+\left(k_{1}\right)_{i, j} u_{i+1 / 2, j}^{n} \frac{u_{i+1, j}^{n+\sigma / 2}-u_{i, j}^{n+\sigma / 2}}{2 h_{x}}+\left(k_{2}\right)_{i, j} u_{i-1 / 2, j}^{n} \frac{u_{i, j}^{n+\sigma / 2}-u_{i-1, j}^{n+\sigma / 2}}{2 h_{x}}+ \\
& +\left(k_{3}\right)_{i, j} v_{i, j+1 / 2}^{n} \frac{u_{i, j+1}^{n+\sigma / 2}-u_{i, j}^{n+\sigma / 2}}{2 h_{y}}+\left(k_{4}\right)_{i, j} v_{i, j-1 / 2}^{n} \frac{u_{i, j}^{n+\sigma / 2}-u_{i, j-1}^{n+\sigma / 2}}{2 h_{y}}= \\
& =\left(k_{1}\right)_{i, j} \mu_{i+1 / 2, j} \frac{u_{i+1, j}^{n+\sigma / 2}-u_{i, j}^{n+\sigma / 2}}{h_{x}^{2}}-\left(k_{2}\right)_{i, j} \mu_{i-1 / 2, j} \frac{u_{i, j}^{n+\sigma / 2}-u_{i-1, j}^{n+\sigma / 2}}{h_{x}^{2}}+ \\
& +\left(k_{3}\right)_{i, j} \mu_{i, j+1 / 2} \frac{u_{i, j+1}^{n+\sigma / 2}-u_{i, j}^{n+\sigma / 2}}{h_{y}^{2}}-\left(k_{4}\right)_{i, j} \mu_{i, j-1 / 2} \frac{u_{i, j}^{n+\sigma / 2}-u_{i, j-1}^{n+\sigma / 2}}{h_{y}^{2}}-\left|\left(k_{3}\right)_{i, j}-\left(k_{4}\right)_{i, j}\right| \frac{\tau_{x}}{\rho h_{y}} m_{i, j} ;
\end{aligned}
$$

under sticking condition:

$$
\begin{aligned}
& \frac{u_{i, j}^{n+\sigma}-\left(k_{0}\right)_{i, j} u_{i, j}^{n}}{\tau}+\left(k_{1,2}\right)_{i, j} u_{i+1 / 2, j}^{n} \frac{u_{i+1, j}^{n+\sigma / 2}-u_{i, j}^{n+\sigma / 2}}{2 h_{x}}+\left(k_{1,2}\right)_{i, j} u_{i-1 / 2, j}^{n} \frac{u_{i, j}^{n+\sigma / 2}-u_{i-1, j}^{n+\sigma / 2}}{2 h_{x}}+ \\
& +\left(k_{3,4}\right)_{i, j} v_{i, j+1 / 2}^{n} \frac{u_{i, j+1}^{n+\sigma / 2}-u_{i, j}^{n+\sigma / 2}}{2 h_{y}}+\left(k_{3,4}\right)_{i, j} v_{i, j-1 / 2}^{n} \frac{u_{i, j}^{n+\sigma / 2}-u_{i, j-1}^{n+\sigma / 2}}{2 h_{y}}= \\
& =\left(k_{1,2}\right)_{i, j} \mu_{i+1 / 2, j} \frac{u_{i+1, j}^{n+\sigma / 2}-u_{i, j}^{n+\sigma / 2}}{h_{x}^{2}}-\left(k_{1,2}\right)_{i, j} \mu_{i-1 / 2, j} \frac{u_{i, j}^{n+\sigma / 2}-u_{i-1, j}^{n+\sigma / 2}}{h_{x}^{2}}+ \\
& +\left(k_{3,4}\right)_{i, j} \mu_{i, j+1 / 2} \frac{u_{i, j+1}^{n+\sigma / 2}-u_{i, j}^{n+\sigma / 2}}{h_{y}^{2}}-\left(k_{3,4}\right)_{i, j} \mu_{i, j-1 / 2} \frac{u_{i, j}^{n+\sigma / 2}-u_{i, j-1}^{n+\sigma / 2}}{h_{y}^{2}},
\end{aligned}
$$


$\left(k_{1,2}\right)_{i, j}=\min \left\{\left(k_{1}\right)_{i, j},\left(k_{2}\right)_{i, j}\right\},\left(k_{3,4}\right)_{i, j}=\min \left\{\left(k_{3}\right)_{i, j},\left(k_{4}\right)_{i, j}\right\}$;

- for the velocity vector $v_{i, j}$ component under slip conditions:

$$
\begin{aligned}
& \left(k_{0}\right)_{i, j} \frac{v_{i, j}^{n+\sigma}-v_{i, j}^{n}}{\tau}+\left(k_{1}\right)_{i, j} u_{i+1 / 2, j}^{n} \frac{v_{i+1, j}^{n+\sigma / 2}-v_{i, j}^{n+\sigma / 2}}{2 h_{x}}+\left(k_{2}\right)_{i, j} u_{i-1 / 2, j}^{n} \frac{v_{i, j}^{n+\sigma / 2}-v_{i-1, j}^{n+\sigma / 2}}{2 h_{x}}+ \\
& +\left(k_{3}\right)_{i, j} v_{i, j+1 / 2}^{n} \frac{v_{i, j+1}^{n+\sigma / 2}-v_{i, j}^{n+\sigma / 2}}{2 h_{y}}+\left(k_{4}\right)_{i, j} v_{i, j-1 / 2}^{n} \frac{v_{i, j}^{n+\sigma / 2}-v_{i, j-1}^{n+\sigma / 2}}{2 h_{y}}= \\
& =\left(k_{1}\right)_{i, j} \mu_{i+1 / 2, j} \frac{v_{i+1, j}^{n+\sigma / 2}-v_{i, j}^{n+\sigma / 2}}{h_{x}^{2}}-\left(k_{2}\right)_{i, j} \mu_{i-1 / 2, j} \frac{v_{i, j}^{n+\sigma / 2}-v_{i-1, j}^{n+\sigma / 2}}{h_{x}^{2}}+ \\
& +\left(k_{3}\right)_{i, j} \mu_{i, j+1 / 2} \frac{v_{i, j+1}^{n+\sigma / 2}-v_{i, j}^{n+\sigma / 2}}{h_{y}^{2}}-\left(k_{4}\right)_{i, j} \mu_{i, j-1 / 2} \frac{v_{i, j}^{n+\sigma / 2}-v_{i, j-1}^{n+\sigma / 2}}{h_{y}^{2}}-\left|\left(k_{1}\right)_{i, j}-\left(k_{2}\right)_{i, j}\right| \frac{\tau_{y}}{\rho h_{x}} m_{i, j} ;
\end{aligned}
$$

under sticking condition:

$$
\begin{aligned}
& \frac{v_{i, j}^{n+\sigma}-\left(k_{0}\right)_{i, j} v_{i, j}^{n}}{\tau}+\left(k_{1,2}\right)_{i, j} u_{i+1 / 2, j}^{n} \frac{v_{i+1, j}^{n+\sigma / 2}-v_{i, j}^{n+\sigma / 2}}{2 h_{x}}+\left(k_{1,2}\right)_{i, j} u_{i-1 / 2, j}^{n} \frac{v_{i, j}^{n+\sigma / 2}-v_{i-1, j}^{n+\sigma / 2}}{2 h_{x}}+ \\
& +\left(k_{3,4}\right)_{i, j} v_{i, j+1 / 2}^{n} \frac{v_{i, j+1}^{n+\sigma / 2}-v_{i, j}^{n+\sigma / 2}}{2 h_{y}}+\left(k_{3,4}\right)_{i, j} v_{i, j-1 / 2}^{n} \frac{v_{i, j}^{n+\sigma / 2}-v_{i, j-1}^{n+\sigma / 2}}{2 h_{y}}= \\
& =\left(k_{1,2}\right)_{i, j} \mu_{i+1 / 2, j} \frac{v_{i+1, j}^{n+\sigma / 2}-v_{i, j}^{n+\sigma / 2}}{h_{x}^{2}}-\left(k_{1,2}\right)_{i, j} \mu_{i-1 / 2, j} \frac{v_{i, j}^{n+\sigma / 2}-v_{i-1, j}^{n+\sigma / 2}}{h_{x}^{2}}+ \\
& +\left(k_{3,4}\right)_{i, j} \mu_{i, j+1 / 2} \frac{v_{i, j+1}^{n+\sigma / 2}-v_{i, j}^{n+\sigma / 2}}{h_{y}^{2}}-\left(k_{3,4}\right)_{i, j} \mu_{i, j-1 / 2} \frac{v_{i, j}^{n+\sigma / 2}-v_{i, j-1}^{n+\sigma / 2}}{h_{y}^{2}} ;
\end{aligned}
$$

- for calculation the pressure field:

$$
\begin{aligned}
& \left(k_{1}\right)_{i, j} \frac{P_{i+1, j}-P_{i, j}}{h_{x}^{2}}-\left(k_{2}\right)_{i, j} \frac{P_{i, j}-P_{i-1, j}}{h_{x}^{2}}+\left(k_{3}\right)_{i, j} \frac{P_{i, j+1}-P_{i, j}}{h_{y}^{2}}-\left(k_{4}\right)_{i, j} \frac{P_{i, j}-P_{i, j-1}}{h_{y}^{2}}= \\
& =\frac{\rho}{\tau}\left(\frac{\left(k_{1}\right)_{i, j} u_{i+1 / 2, j}^{n+\sigma}-\left(k_{2}\right)_{i, j} u_{i-1 / 2, j}^{n+\sigma}}{h_{x}}+\frac{\left(k_{2}\right)_{i, j}-\left(k_{1}\right)_{i, j}}{h_{x}} U_{i, j}+\right. \\
& \left.+\frac{\left(k_{3}\right)_{i, j} v_{i, j+1 / 2}^{n+\sigma}-\left(k_{4}\right)_{i, j} v_{i, j-1 / 2}^{n+\sigma}}{h_{y}}+\frac{\left(k_{4}\right)_{i, j}-\left(k_{3}\right)_{i, j}}{h_{y}} V_{i, j}\right) ;
\end{aligned}
$$

- equations to refine the velocity field by pressure:

$$
\begin{aligned}
& \left(k_{0}\right)_{i, j} \frac{u_{i, j}^{n+1}-u_{i, j}^{n+\sigma}}{\tau}=-\left(\left(k_{1}\right)_{i, j} \frac{P_{i+1, j}^{n+1}-P_{i, j}^{n+1}}{2 h_{x} \rho}+\left(k_{2}\right)_{i, j} \frac{P_{i, j}^{n+1}-P_{i-1, j}^{n+1}}{2 h_{x} \rho}\right), \\
& \left(k_{0}\right)_{i, j} \frac{v_{i, j}^{n+1}-v_{i, j}^{n+\sigma}}{\tau}=-\left(\left(k_{3}\right)_{i, j} \frac{P_{i, j+1}^{n+1}-P_{i, j}^{n+1}}{2 h_{y} \rho}+\left(k_{4}\right)_{i, j} \frac{P_{i, j}^{n+1}-P_{i, j-1}^{n+1}}{2 h_{y} \rho}\right) .
\end{aligned}
$$

It is shown that the order of approximation of the system of equations is $O\left(\tau+h_{x}^{2}+h_{y}^{2}\right)$. The sufficient condition for the stability of the scheme for the method of «corrections to pressure» is 
determined on the basis of the grid maximum principle [17] with spacing values restrictions: $h_{x}<\left|\frac{2 \mu}{u}\right|, h_{y}<\left|\frac{2 \mu}{v}\right|$ or $\operatorname{Re} \leq 2 N$, where $\operatorname{Re}=u \cdot l / \mu$ is the Reynolds number, $u$ is the velocity of the aquatic environment, $l$ is the characteristic size of the region, $\mu$ is the turbulent exchange coefficient.

To solve the grid equations obtained, an adaptive modified alternating-triangular method of variational type was applied, which is advanced variant of SSOR method.

Taylor-Couette flow. Let us consider the steady flow of fluid between two infinitely long coaxial circular cylinders

$$
u u_{x}^{\prime}+v u_{y}^{\prime}=-\rho^{-1} P_{x}^{\prime}+\mu \Delta u, u v_{x}^{\prime}+v v_{y}^{\prime}=-\rho^{-1} P_{y}^{\prime}+\mu \Delta v, r_{1} \leq r \leq r_{2}, r=\sqrt{x^{2}+y^{2}} .
$$

Suppose, on the internal side, the rotation speed is $\mid \mathbf{u} \|_{r=r_{1}}=u_{1}$, on the external side, the rotation speed is $\mid \mathbf{u} \|_{r=r_{2}}=u_{2}$. The polar coordinate system was introduced to solve the problem $(x=r \cos \theta, y=r \sin \theta)$

$$
\begin{aligned}
& u_{r} \frac{\partial u_{r}}{\partial r}+\frac{u_{\theta}}{r} \frac{\partial u_{r}}{\partial \theta}-\frac{u_{\theta}^{2}}{r}=-\frac{1}{\rho} \frac{\partial P}{\partial r}+\mu\left(\frac{\partial}{\partial r}\left(\frac{1}{r} \frac{\partial\left(r u_{r}\right)}{\partial r}\right)+\frac{1}{r^{2}} \frac{\partial^{2} u_{r}}{\partial \theta^{2}}-\frac{2}{r^{2}} \frac{\partial u_{\theta}}{\partial \theta}\right), \\
& u_{r} \frac{\partial u_{\theta}}{\partial r}+\frac{u_{\theta}}{r} \frac{\partial u_{\theta}}{\partial \theta}+\frac{u_{\theta} u_{r}}{r}=-\frac{1}{r \rho} \frac{\partial P}{\partial \theta}+\mu\left(\frac{\partial}{\partial r}\left(\frac{1}{r} \frac{\partial\left(r u_{\theta}\right)}{\partial r}\right)+\frac{1}{r^{2}} \frac{\partial^{2} u_{\theta}}{\partial \theta^{2}}+\frac{2}{r^{2}} \frac{\partial u_{r}}{\partial \theta}\right) .
\end{aligned}
$$

Taking into account that $v_{r}=0, v_{\theta}=v_{\theta}(r)$ and $P=P(r)$, we obtain:

$$
\frac{1}{\rho} \frac{\partial P}{\partial r}=\frac{u_{\theta}^{2}}{r}, \frac{\partial}{\partial r}\left(\frac{1}{r} \frac{\partial\left(r u_{\theta}\right)}{\partial r}\right)=0 \text {. }
$$

The analytical solution of this system of equations is:

$$
u_{\theta}(r)=c_{1} r+c_{2} / r, P(r)=P\left(r_{1}\right)+\rho \int_{r_{1}}^{r}\left(u_{\theta}^{2} / r\right) d r .
$$

To compare the results of numerical calculations with the analytical solution, we take $r_{1}=5 \mathrm{~m}, r_{2}=10 \mathrm{~m}, u_{1}=1 \mathrm{~m} / \mathrm{s}, u_{2}=0.5 \mathrm{~m} / \mathrm{s}$.

In this case, the analytical solution takes the form

$$
u_{\theta}(r)=5 / r, P(r)=P\left(r_{1}\right)-12.5 \rho / r^{2}+\rho / 2 \text {. }
$$

The analytical solution in the Cartesian coordinate system takes the form

$$
u(x, y)=-\frac{5 y}{x^{2}+y^{2}}, v(x, y)=\frac{5 x}{x^{2}+y^{2}}, P(x, y)=P\left(r_{1}\right)-\frac{12.5 \rho}{x^{2}+y^{2}}+\rho / 2 \text {. }
$$

Results of numerical experiments. The problem of finding the numerical flow of a viscous fluid between two coaxial cylinders $(x \geq 0)$ is considered. The inside cylinder radius is $r_{1}=5 \mathrm{~m}$. The outside cylinder radius is $r_{2}=10 \mathrm{M}$. The calculated domain is inscribed in a rectangle with dimensions $10 \times 20 m(0 \leq x \leq 10,-10 \leq y \leq 10)$. In the section of the cylinder by the plane $x=0$ sets the velocity 
field $u(0, y)=-5 / y \mathrm{~m} / \mathrm{s}, v(0, y)=0 \mathrm{~m} / \mathrm{s}$. In all other grid nodes, the velocity field is calculated. On the inside and outside walls of the cylinder, the conditions for slip and non-flow are specified.

Defects of numerical solutions are most clearly visible on coarse grids. We describe the parameters of a coarse grid. The steps in the spatial directions are $1 \mathrm{~m}$, the time step is $0.1 \mathrm{~s}$, the mesh size is $21 \times 11$ knots, the length of the counting interval is $10 \mathrm{~s}$, the density is $\rho=1000 \mathrm{~kg} / \mathrm{m}^{3}$, the turbulent exchange coefficient is $\mu=1 \mathrm{~m}^{2} / \mathrm{s}$. Fig. 4 shows the contents of an array describing the degree of filling of cells in the case of using the grid of $21 \times 11$ nodes.

\begin{tabular}{|c|c|c|c|c|c|c|c|c|c|c|}
\hline & 0 & 1 & 2 & 3 & 4 & 5 & 6 & 7 & 8 & 9 \\
\hline \begin{tabular}{|l|}
0 \\
\end{tabular} & 0.983 & 0.883 & 0.678 & 0.362 & 0.03 & 0 & 0 & 0 & 0 & 0 \\
\hline 1 & 1 & 1 & 1 & 1 & 0.894 & 0.344 & 0 & 0 & 0 & 0 \\
\hline 2 & 1 & 1 & 1 & 1 & 1 & 1 & 0.59 & 0.01 & 0 & 0 \\
\hline 3 & 1 & 1 & 1 & 1 & 1 & 1 & 1 & 0.59 & 0 & 0 \\
\hline 4 & 1 & 1 & 1 & 1 & 1 & 1 & 1 & 1 & 0.344 & 0 \\
\hline 5 & 0.034 & 0.24 & 0.683 & 1 & 1 & 1 & 1 & 1 & 0.894 & 0.03 \\
\hline 6 & 0 & 0 & 0 & 0.453 & 1 & 1 & 1 & 1 & 1 & 0.362 \\
\hline 7 & 0 & 0 & 0 & 0 & 0.683 & 1 & 1 & 1 & 1 & 0.678 \\
\hline 8 & 0 & 0 & 0 & 0 & 0.24 & 1 & 1 & 1 & 1 & 0.883 \\
\hline 9 & 0 & 0 & 0 & 0 & 0.034 & 1 & 1 & 1 & 1 & 0.983 \\
\hline 10 & 0 & 0 & 0 & 0 & 0.034 & 1 & 1 & 1 & 1 & 0.983 \\
\hline 11 & 0 & 0 & 0 & 0 & 0.24 & 1 & 1 & 1 & 1 & 0.883 \\
\hline 12 & 0 & 0 & 0 & 0 & 0.683 & 1 & 1 & 1 & 1 & 0.678 \\
\hline 13 & 0 & 0 & 0 & 0.453 & 1 & 1 & 1 & 1 & 1 & 0.362 \\
\hline 14 & 0.034 & 0.24 & 0.683 & 1 & 1 & 1 & 1 & 1 & 0.894 & 0.03 \\
\hline 15 & 1 & 1 & 1 & 1 & 1 & 1 & 1 & 1 & 0.344 & 0 \\
\hline 16 & 1 & 1 & 1 & 1 & 1 & 1 & 1 & 0.59 & 0 & 0 \\
\hline 17 & 1 & 1 & 1 & 1 & 1 & 1 & 0.59 & 0.01 & 0 & 0 \\
\hline 18 & 1 & 1 & 1 & 1 & 0.894 & 0.344 & 0 & 0 & 0 & 0 \\
\hline 19 & 0.983 & 0.883 & 0.678 & 0.362 & 0.03 & 0 & 0 & 0 & 0 & 0 \\
\hline
\end{tabular}

Fig. 4. The values of the filling of cells for the grid of $21 \times 11$ nodes

Fig. 5 shows the numerical solution of the problem of fluid flow between two coaxial cylinders. The color shows the flow of fluid $\left|k_{0} \mathbf{u}\right|$.
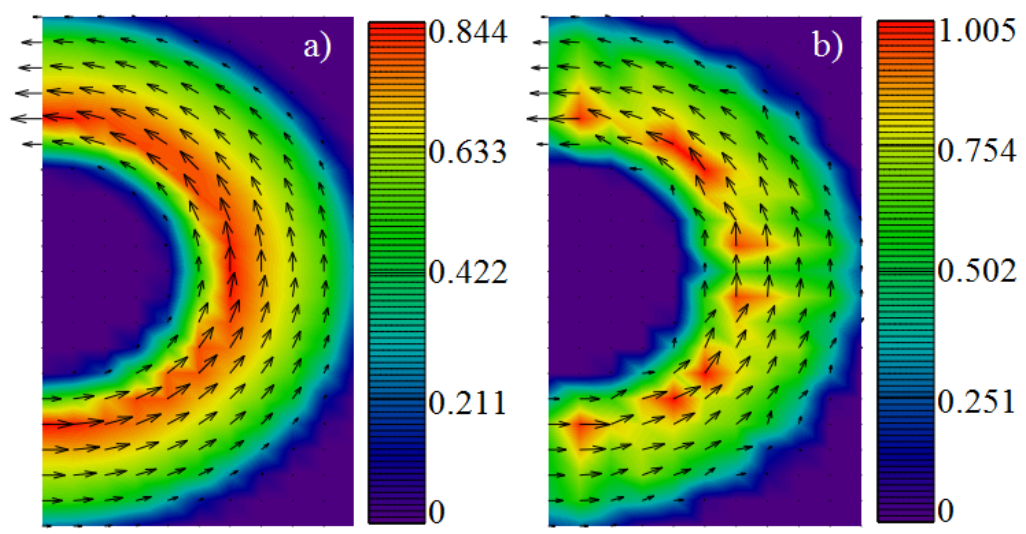

Fig. 5. Numerical solution of the problem: a) in case of partial filling of cells, b) in case of piecewise rectangular interface between two media

Fig. 6. a) shows that the solution of the problem of fluid flow between two coaxial cylinders, obtained on grids that take into account the filling of the cells, is sufficiently smooth. Fig. 6. b) shows 
the solution with defects associated with piecewise rectangular approximation of the interface between two media.
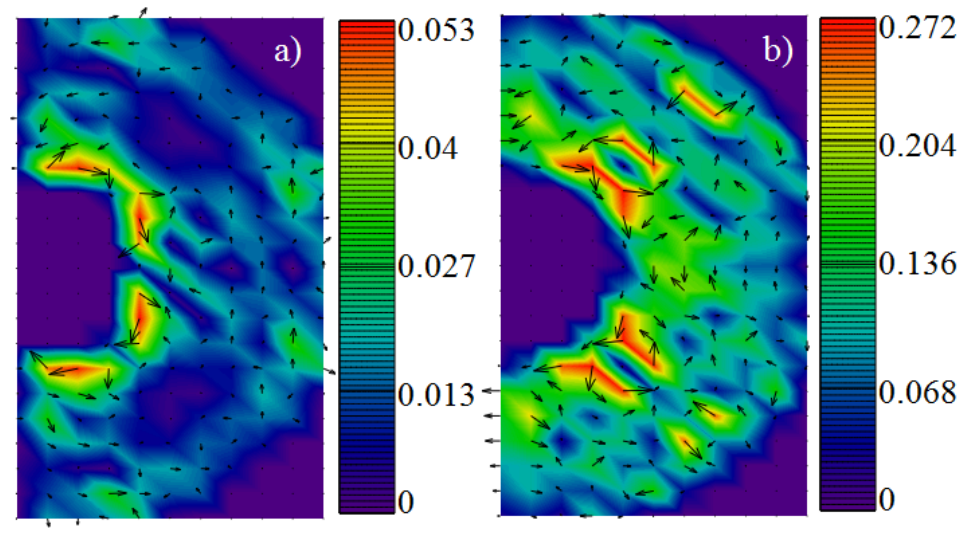

Fig. 6. The error distribution obtained as the difference between the numerical and analytical solutions of the problem: a) in case of a smooth boundary, b) in case of a step boundary

Fig. 7 and 8 show the errors in the numerical solution of the problem of fluid flow between two coaxial cylinders on grids taking into account the filling of the cells (in case of a smooth boundary) and on grids with piecewise rectangular approximation of the boundary. For numerical investigation of the accuracy of the proposed schemes, a solution is found on a sequence of condensing grids. Fig. 8 presents the numerical solution of the initial problem of fluid flow between two coaxial cylinders on more detailed grids of sizes $21 \times 41$ and $41 \times 81$ knots.

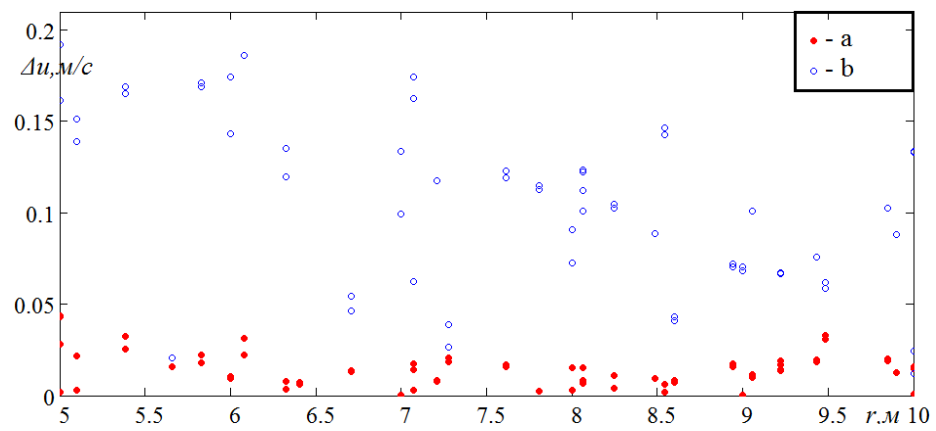

Fig. 7. The dependence of the error from the radius: a) in case of smooth boundary, b) in case of step boundary
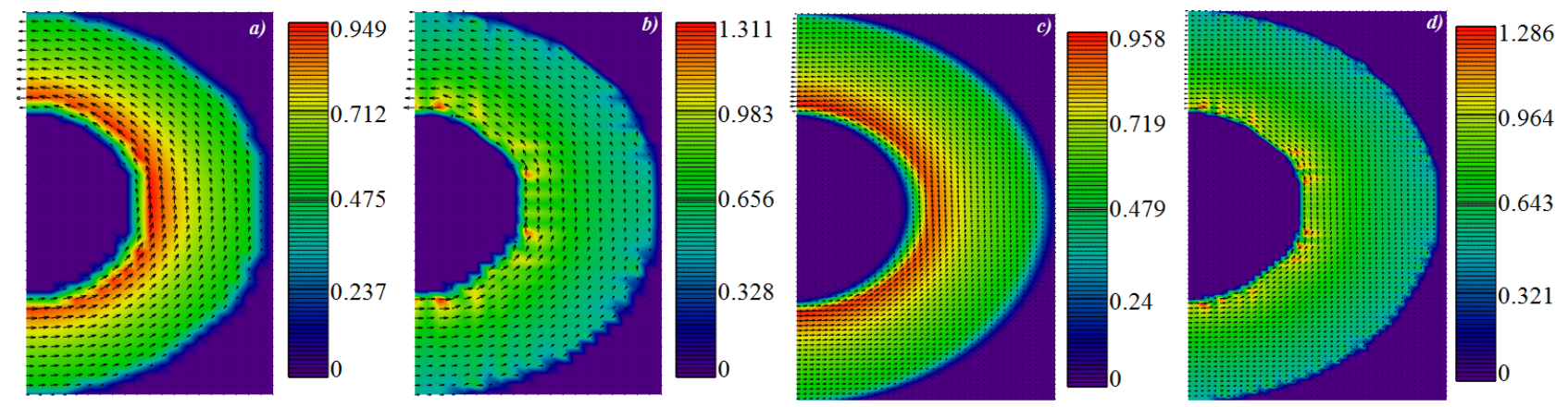

Fig. 8. The numerical solution of the problem: a), c) in case of using partial filling of cells; b), d) in case of stepped interface between two media; a), b) dimensions of the computational grid $21 \times 41$ knots; c), d) dimensions of the computational grid $41 \times 81$ knots 
Fig. 9 shows the error values of the numerical solution of the fluid flow problem, depending on the radius (circles indicate the error in case of a smooth boundary, circles indicate the error in the case of a step boundary).
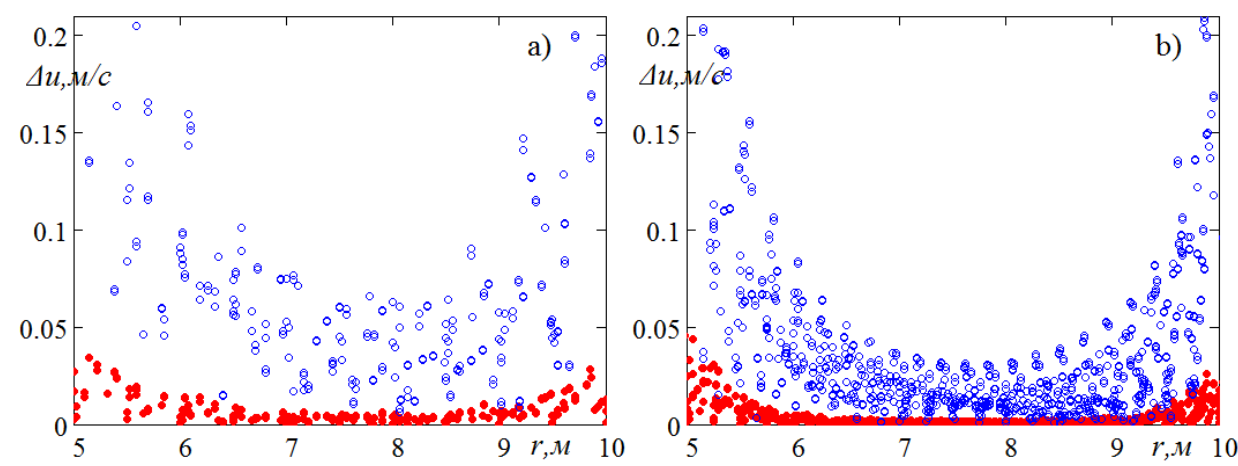

Fig. 9. The dependence of the error in the solution of the problem of fluid flow between two cylinders from the radius on a grid of dimensions: a) $21 \times 41$ knots, b) $41 \times 81$ knots

Fig. 7, 9 show that the increase in the size of the calculated grids for the problem of flow of the aqueous medium does not lead to an increase in the accuracy in case of piecewise rectangular approximation of the boundary, but to a decrease in the linear dimensions of the border region where the solutions of the solution associated with rough approximation of the boundary are manifested. It should also be noted that when using grids taking into account the filling of cells, the error in the numerical solution of model hydrodynamic problems caused by the approximation of the boundary does not exceed $6 \%$ of the solution of the problem.

Table 1 presents the error values of the numerical solution of the fluid flow problem between two coaxial cylinders obtained from a sequence of condensing computed grids $11 \times 21,21 \times 41,41$ $\times 81$, and $81 \times 161$ nodes in case of a smooth and stepped boundary.

Table 1. The error in the solution of the problem of fluid flow between two cylinders

\begin{tabular}{l|l|l|l|l}
\hline Grid dimensions & $11 \times 21$ & $21 \times 41$ & $41 \times 81$ & $81 \times 161$ \\
\hline The maximum error value in the case of a smooth boundary, $\mathrm{m} / \mathrm{s}$ & 0.053 & 0.052 & 0.058 & 0.056 \\
\hline The average error value in the case of a smooth boundary, $\mathrm{m} / \mathrm{s}$ & 0.023 & 0.012 & 0.006 & 0.003 \\
\hline The maximum error value in the case of a stepped boundary, $\mathrm{m} / \mathrm{s}$ & 0.272 & 0.731 & 0.717 & 0.75 \\
\hline The average error value in the case of a stepped boundary, $\mathrm{m} / \mathrm{s}$ & 0.165 & 0.132 & 0.069 & 0.056 \\
\hline
\end{tabular}

The analysis of the error calculating results of the numerical solution of the problem of fluid flow between two cylinders on the sequence of condensing grids presented in Table 1 allows us to conclude that the use of difference schemes taking into account the filling of cells is effective. The grid splitting by 8 times in each of the spatial directions does not lead to an increase in the accuracy that solutions obtained on grids taking into account the filling of the cells possess.

Conclusion. The paper considers the problem of searching the numerical flow of a viscous fluid between two coaxial half-cylinders. Analytic solution describing the Taylor-Couette flow is used as a standard to evaluate the accuracy of the numerical solution of hydrodynamic problems. The simulation was performed on a sequence of condensing computed grids of sizes $11 \times 21,21 \times 41,41$ 
$\times 81$, and $81 \times 161$ nodes in cases of smooth and piecewise rectangular boundaries. To improve the solution smoothness we used grids taking into account the filling of the cells.

In the case of piecewise rectangular approximation the error of numerical solution reaches $70 \%$. The grids taking into account the filling of cells reduce the numerical solution error to $6 \%$. It is shown that crushing the grid by 8 times in each spatial direction does not lead to increasing the accuracy solutions whereas the solutions accuracy obtained on grids taking into account the filling of cells significantly increases.

\section{References}

1. А.И. Сухинов, А.Е. Чистяков, Е.Ф. Тимофеева, А.В. Шишеня. Математическая модель расчета прибрежных волновых процессов // Математическое моделирование, 2012. Т. 24, № 8. C. 32-44.

A.I. Sukhinov, A.E. Chistyakov, E.F. Timofeeva, A.V. Shishenya. Mathematical model for calculating coastal wave processes // Mathematical Models and Computer Simulations, 2013. Volume 5. Issue 2, p.122-129.

2. А.И. Сухинов, А.Е. Чистяков, Е.В. Алексеенко. Численная реализация трехмерной модели гидродинамики для мелководных водоемов на супервычислительной системе // Математическое моделирование, 2011. Т. 23, № 3. С.3-21.

A. I. Sukhinov, A. E. Chistyakov, and E. V. Alekseenko, Numerical Realization of the ThreeDimensional Model of Hydrodynamics for Shallow Water Basins on a High-Performance System // Mathematical Models and Computer Simulations, 2011. Volume 23. Issue 3, pp.3-21.

3. А.И. Сухинов, А.Е. Чистяков, А.В. Шишеня, Е.Ф. Тимофеева. Предсказательное моделирование прибрежных гидрофизических процессов на многопроцессорной системе с использованием явных схем // Математическое моделирование, 2018. Т. 30. № 3. С. 83-100.

A.I. Sukhinov, A.Ye. Chistyakov, A.V. Shishenya, Ye.F. Timofeyeva. Predskazatel'noye modelirovaniye pribrezhnykh gidrofizicheskikh protsessov na mnogoprotsessornoy sisteme $\mathrm{s}$ ispol'zovaniyem yavnykh skhem // Matematicheskoye modelirovaniye, 2018. T.30, № 3. S. 83-100.

4. T. Ezer, G.L. Mellor Sensitivity studies with the North Atlantic sigma coordinate Princeton Ocean Model. Dynamics of Atmospheres and Oceans. 2000. V. 32. pp. 155-208.

5. А.С. Монин. Турбулентность и микроструктура в океане // Успехи физических наук, 1973. T. 109, № 2. C.333-354.

A.S. Monin. Turbulentnost' i mikrostruktura v okeane // Uspekhi fizicheskikh nauk, 1973. T. 109, № 2. S.333-354.

6. Ю.И. Шокин. Вычислительный эксперимент в проблеме цунами / Ю.И. Шокин, Л. Б. Чубаров, Ан. Г. Марчук, К.В. Симонов. - Новосибирск: Наука. Сиб. отд-ние, 1989. 164 с.

Yu.I. Shokin. Vychislitel'nyy eksperiment v probleme tsunami / YU.I. Shokin, L. B. Chubarov, An. G. Marchuk, K.V. Simonov. - Novosibirsk: Nauka. Sib. otd-napravleniye, 1989. 164 s.

7. Ю.В. Василевский, А.А. Данилов, Д.В. Николаев, С.Г. Руднев, В.Ю. Саламатова, А.В. Смирнов. Конечно-элементный анализ задач биоимпедансной диагностики // Ж. вычисл. матем. и матем. физ., 2012. Т. 52, № 4. С. 733-745. 
Yu.V. Vasilevskiy, A.A. Danilov, D.V. Nikolayev, S.G. Rudnev, V.YU. Salamatova, A.V. Smirnov. Konechno-elementnyy analiz zadach bioimpedansnoy diagnostiki // ZH. vychisl. matem. i matem. fiz., 2012. T. 52, № 4. S. 733-745.

8. М.В. Муратов, И.Б. Петров, И.Е. Квасов. Численное решение задач сейсморазведки в зонах трещиноватых резервуаров // Математическое моделирование, 2016. Т. 28, № 7. С.3144.

M.V. Muratov, I.B. Petrov, I.Ye. Kvasy. Chislennoye resheniye zadach seysmorazvedki v skvazhinakh treshchinovatykh rezervuarov // Matematicheskoye modelirovaniye, 2016. T. 28, № 7. S.31-44.

9. Б.Н. Четверушкин, М.В. Якобовский. Вычислительные алгоритмы и архитектура систем высокой производительности // Препринты ИПМ им. М.В.Келдыша, 2018, 052, 12 с.

B.N. Chetverushkin, M.V. Yakobovskiy. Vychislitel'nyye algoritmy i arkhitektura sistem vysokoy proizvoditel'nosti // Preprinty IPM im. M.V.Keldysha, 2018, 052, $12 \mathrm{s.}$

10. Л.Д. Ландау., Е.М. Лифшиц. Гидродинамика. - М.: Наука, Гл. ред. физ-мат.лит., 1986. $736 \mathrm{c}$.

L.D. Landau., Ye.M. Lifshits. Gidrodinamika. - M .: Nauka, Gl. red. fiz-mat.lit., 1986. 736 s.

11. О.М. Белоцерковский. Турбулентность: новые подходы. - М.: Наука, 2003. 286 с.

O.M. Belotserkovskiy. Turbulentnost': novyye podkhody. - M.: Nauka, 2003. 286 s.

12. О.М. Белоцерковский, В.А.Гущин, В.В. Щенников. Метод расщепления в применении к решению задач динамики вязкой несжимаемой жидкости // Ж. вычисл. матем. и матем. физ., 1975. Т. 15, №1. С.197-207.

O.M.BelotserkovskiiV.A.GushchinV.V.Shchennikov. Use of the splitting method to solve problems of the dynamics of a viscous incompressible fluidUSSR // Computational Mathematics and Mathematical Physics, 1975. Volume 15. Issue 1, pp. 190-200.

13. О.М. Белоцерковский, В.А. Гущин, В.Н. Коньшин. Метод расщепления для исследования течений стратифицированной жидкости со свободной поверхностью // Ж. вычисл. матем. и матем. физ., 1987, Т. 27, № 4. С. 594-609.

O.M. Belotserkovskiy, V.A. Gushchin, V.N. Kon'shin. The splitting method for investigating flows of a stratified liquid with a free surface // USSR Computational Mathematics and Mathematical Physics. 1987. Volume 27. Issue 2, pp. 181-191.

14. А.И. Сухинов, А.Е. Чистяков, Н.А. Фоменко. Методика построения разностных схем для задачи диффузии-конвекции-реакции, учитывающих степень заполненности контрольных ячеек // Известия ЮФУ. Технические науки, 2013. № 4 (141). С. 87-98.

A.I. Sukhinov, A.Ye. Chistyakov, N.A. Fomenko. Metodika postroyeniya raznostnykh skhem dlya resheniya zadach diffuzii-konvektsii-reaktsii, uchityvayushchikh stepen' zapolnennosti kontrol'nykh yacheyek // Izvestiya YUFU. Tekhnicheskiye nauki, 2013. № 4(141). S. 87-98.

15. А.А. Самарский. Теория разностных схем. - М.: Наука, 1989. 616 с.

A.A. Samarskii. The theory of difference schemes. - NY - Basel, Marcel Dekker, Inc, 2001, $761 \mathrm{p}$.

16. А.А. Самарский, П.Н. Вабищевич. Численные методы решения задач конвекциидиффузии. - М.: Эдиториал УРСС, 1999. 247 с. 
A.A. Samarskiy, P.N. Vabishchevich. Chislennyye metody resheniya zadach konvektsiidiffuzii. - M .: Editorial URSS, 1999. 247 s.

17. А.А. Самарский, Е.С. Николаев. Методы решения сеточных уравнений. - М.: Наука, 1978. 592 с.

A.A. Samarskiy, Ye.S. Nikolayev. Metody resheniya setochnykh uravneniy. - M .: Nauka, 1978. $592 \mathrm{~s}$.

18. А.Н. Коновалов. К теории попеременно-треугольного итерационного метода // Сибирский математический журнал, 2002. Т. 43, № 3. С. 552-572.

A. N. Konovalov, To the Theory of the Alternating Triangle Iteration Method, Sib. Mat. Zh. 43 (3), 552-572 (2002). [Sib. Math. J. 43 (3), 439-457 (2002)].

19. А.И. Сухинов, А.Е. Чистяков. Адаптивный модифицированный попеременнотреугольный итерационный метод для решения сеточных уравнений с несамосопряженным оператором // Математическое моделирование, 2012. Т. 24, № 1. С. 3-20.

A.I. Sukhinov, A.E. Chistyakov, Adaptive Modified Alternating Triangular Iterative Method for Solving Grid Equations with a NonSelfAdjoint Operator // Matematicheskoe Modelirovanie, 2012, Vol. 24, No. 1, pp. 3-20.

20. С.В. Валландер. Лекции по гидроаэромеханике. Учеб. пособие. - Л.: Изд-во ЛГУ, 1978. $296 \mathrm{c}$.

S.V. Vallander. Lektsii po gidroaeromekhanike. Ucheb. posobiye. - L.: LGU, 1978. 296 s.

Authors:

Sukhinov Alexander Ivanovich, Don State Technical University (1st Gagarin Square, Rostov-onDon, Russian Federation), Doctor of Science in Physics and Maths, Professor

Chistyakov Alexander Evgenievich, Don State Technical University (1st Gagarin Square, Rostovon-Don, Russian Federation), Doctor of Science in Physics and Maths, Associate professor

Protsenko Elena Anatolevna, Taganrog Institute of A.P. Chekhov (branch) RSUE (Initiative Street, Taganrog, Russian Federation), Candidate of Science in Physics and Maths, Associate professor

Sidoryakina Valentina Vladimirovna, Taganrog Institute of A.P. Chekhov (branch) RSUE (Initiative Street, Taganrog, Russian Federation), Candidate of Science in Physics and Maths, Associate professor

Protsenko Sofya Vladinirovna, Don State Technical University (1st Gagarin Square, Rostov-onDon, Russian Federation), postgraduate student 


\section{Повышение гладкости численного решения моделирования задач гидродинамики на прямоугольных сетках *}

\section{А.И. Сухинов, А.Е. Чистяков ${ }^{* *}$, Е.А. Проценко, В.В. Сидорякина ${ }^{* * *}$, С.В. Проценко ${ }^{* *}$}

Донской государственный технический университет, Ростов-на-Дону, Российская Федерация Таганрогский институт имени А.П. Чехова (филиал) Ростовского государственного экономического университета (РИНХ), Таганрог, Российская Федерация

В работе рассматривается развитие и применение метода учета заполненности прямоугольных ячеек материальной средой, в частности, жидкостью для повышения гладкости и точности конечноразностного решения задач гидродинамики со сложной формой граничной поверхности. Для исследования возможностей предлагаемого метода рассмотрены две задачи вычислительной гидродинамики - пространственно-двумерного течения вязкой жидкости между двумя соосными полуцилиндрами и пространственно-трехмерная задача волновой гидродинамики - распространения волны в прибрежной зоне и ее выхода на сушу. Для решения поставленных задач используются прямоугольные сетки, учитывающие заполненность ячеек. Аппроксимация задач по времени выполнена на основе схем расщепления по физическим процессам, а по пространственным переменным - на основе интегро-интерполяционного метода с учетом заполненности ячеек и без ее учета. Для оценки точности численного решения первой задачи в качестве эталона используется аналитическое решение, описывающее течение Куэтта-Тейлора. Моделирование производилось на последовательности сгущающихся расчетных сеток размерами: $11 \times 21,21 \times 41,41 \times 81$ и $81 \times 161$ узлов в случае применения метода и без его использования. В случае непосредственного использования прямоугольных сеток (ступенчатой аппроксимации границ) относительная погрешность расчетов достигает 70\%; при тех же условиях использование предлагаемого метода позволяет уменьшить погрешность до 6\%. Показано, что дробление прямоугольной сетки в 2-8 раз по каждому из пространственных направлений не приводит к такому же повышению точности, которой обладают численные решения, полученные с учетом заполненности ячеек..

Ключевые слова: схемы расщепления по физическим процессам, течение КуэттаТейлора, погрешность численного решения.

\footnotetext{
* Работа выполнена при поддержке РНФ (проект № 17-11-01286).

**E-mail: sukhinov@gmail.com, cheese_05@mail.ru, rab55555@rambler.ru.

***E-mail: eapros@rambler.ru, cvv9@mail.ru.
} 


\section{Авторы:}

Сухинов Александр Иванович, Донской государственный технический университет (344000 Ростов-на-Дону, пл. Гагарина, д. 1), доктор физико-математических наук, профессор

Чистяков Александр Евгеньевич, Донской государственный технический университет (344000 Ростов-на-Дону, пл. Гагарина, д. 1), доктор физико-математических наук, доцент

Проценко Елена Анатольевна, Таганрогский институт им. А.П. Чехова (филиал) РГЭУ (РИНЭ) (347936 Таганрог, улица Инициативная, д. 48), кандидат физико-математических наук

Сидорякина Валентина Владимировна, Таганрогский институт им. А.П. Чехова (филиал) РГЭУ (РИНЭ) (347936 Таганрог, улица Инициативная, д. 48), кандидат физикоматематических наук, доцент

Проценко Софья Владимировна, Донской государственный технический университет (344000 Ростов-на-Дону, пл. Гагарина, д. 1), аспирант 